\title{
Model Cognitive Stage Experiential (CSE) dan Kesadaran Dini Kebhinekatunggalikaan Siswa SD Kelas Rendah
}

\author{
IM Hambali \\ Jurusan Bimbingan dan Konseling-Fakultas Ilmu Pendidikan-Universitas Negeri Malang- \\ Jl.Semarang No. 5, Malang, Jawa Timur 65145 \\ E-mail: im.hambali.fip@um.ac.id
}

Artikel diterima: 2 Desember 2016; direvisi 29 Desember 2016; disetujui: 29 Desember 2016

\begin{abstract}
Abstrak: Penelitian ini bertujuan untuk mengetahui: (1) proporsi tingkat kesadaran bhineka tunggal ika yang masuk kategori sangat rendah; (2) proporsi tingkat kesadaran bhineka tunggal ika yang masuk kategori rendah; (3) proporsi tingkat kesadaran bhineka tunggal ika yang masuk kategori sedang; (4) proporsi tingkat kesadaran bhineka tunggal ika yang masuk kategori tinggi; (5) proporsi tingkat kesadaran bhineka tunggal ika yang masuk kategori sangat tinggi. Hasil penelitian menunjukkan bahwa: (1) proporsi tingkat kesadaran bhineka tunggal ika yang masuk kategori sangat rendah adalah 42.5\%, 43\% dan 41\%; (2) proporsi tingkat kesadaran bhineka tunggal ika yang masuk kategori rendah adalah $20 \%$, 20\%, 22\%; (3) proporsi tingkat kesadaran bhineka tunggal ika yang masuk kategori sedang adalah $27 \%$, 25\%, dan 26\%; (4) proporsi tingkat kesadaran bhineka tunggal ika yang masuk kategori tinggi adalah 5\%, 9\%, 7\%; (5) proporsi tingkat kesadaran bhineka tunggal ika yang masuk kategori sangat tinggi adalah 6\%, 3\%, $4 \%$.
\end{abstract}

Kata kunci: kesadaran bhineka tunggal ika; cognitive stage experiential

Siswa yang berbeda kelompok, asal tempat tinggal dan budaya, latar belakang keluarga, agama, dan etnis bertemu saling berinteraksi dalam komunitas sekolah. Interaksi sosial pada kelompok yang memiliki keragaman memerlukan pemahaman budaya (Matsumoto,1996), demikian juga perubahan dan kompleksitas kehidupan masyarakat ke arah bhineka tunggal ika memengaruhi berbagai aspek kehidupan. Dalam konteks pendidikan di sekolah, kesadaran keberagaman kelompok, etnis dan bhineka tunggal ika setiap individu sangat diperlukan dan menjadi perekat bagi keharmonisan dalam setiap interaksi antara individu dalam sekolah. Kesadaran bhineka tunggal ika menjadi lebih bermakna manakala siswa dipandang sebagai makhluk sosial yang sedang berkembang menuju pada pencapaian optimal di masa mendatang.

Perkelahian antar kelompok pelajar seperti terjadi di Sulawesi Selatan dalam suasana upacara bendera memperingati HUT ke 65 Indonesia Merdeka, tindakan negatif berlebihan yang dilakukan oleh geng motor yang sangat meresahkan, pergaulan bebas, termasuk juga tawuran mahasiswa di Ternate saat melaksanakan kegiatan PKPT mahasiswa baru, (Metro TV,Rabu 1 September 2010), tawuran antar kelompok pelajar di Tangerang Banten (TV-One, Senin 25 September 2010), dan masih banyak lagi contoh lainnya sebenarnya wujud nyata adanya rendahnya kesadaran bhineka tunggal ika dan terbentuknya tindakan irrational. Tindakan menyerang (agresif) kepada orang lain, marah yang memuncak dan bersifat emosional merupakan tindakan yang mencerminkan adanya ketidakselarasan antara pikiran, emosi dan tindakan. Emosi, (Goleman, 1995) pada dasarnya adalah dorongan spontanitas untuk bertindak seketika dalam rangka mengatasi masalah yang dihadapi oleh individu. Emosi memiliki pola tindakan fisiologis khas yang berbeda dan ditentukan oleh 
pengalaman hidup dan khas berdasarkan budaya. Pikiran dan emosi, dalam sebagian besar tindakan manusia selalu berinteraksi dalam menetapkan sebuah tindakan yang menurutnya tepat. Ledakan emosional seperti halnya dikemukakan oleh Goleman (1995), misalnya sangat marah atau sangat gembira, merupakan pembajakan saraf. Pada saat terjadi ledakan emosional, misalnya sekelompok mahasiswa menyaksikan pemukulan terhadap salah seorang dosennya oleh kelompok mahasiswa tertentu, amigdala, sebuah pusat di otak limbic mengumumkan keadaan darurat sambil menghimpun bagian-bagian lain dari otak untuk mendukung agendanya yang mendesak. Pembajakan tersebut berlangsung seketika, dan memicu reaksi terhadap momen penting sebelum neokorteks (bagian otak yang berpikir) memahami sepenuhnya apa yang terjadi, muncullah aksi pengeroyokan oleh kelompok mahasiswa (yang menyaksikan pemukulan) terhadap kelompok mahasiswa (yang memukul seorang dosen) dan terjadilah perkelahian antar kelompok mahasiswa. Peristiwa ini dapat terjadi berulang pada kelompok atau individu lain dalam waktu dan situasi berbeda, bahkan siswa sebagai remaja yang menyaksikan tidak luput dari pengaruh negatif peristiwa tersebut. Semua kejadian negatif tersebut bersumber dari rendahnya kesadaran bhineka tunggal ika.

Need assessment dilakukan dengan mengajukan sejumlah pertanyaan kepada colon pengguna yang hasilnya dipergunakan sebagai bahan pertimbangan dan rujukan dalam menetapkan prototipe model. Oleh karena itu, need assessment dilakukan sebelumnya dilakukan rancang bangun sesuai dengan spesifikasi produk yang telah direncanakan.

Kesadaran bhineka tunggal ika bukanlah suatu keterampilan, namun lebih kepada proses belajar yang mengarah pada kemampuan seseorang dalam memberikan penilaian secara efektif terhadap berbagai tantangan dan kesempatan yang diberikan oleh sistem sosial yang mengedepankan keragaman sosio-kultural (Cox \& Ruby, 1997). Kesadaran multicultural merupakan bagian dari domain standar kompetensi kemandirian peserta didik, dimana siswa harus dapat menghargai dan memahami keberadaan kultur orang lain dan posisinya dalam konteks membina hubungan sosial yang efektif. Standar kompetensi bhineka tunggal ika mencakup: (1) kesadaran nilai-nilai kultur diri sendiri dan potensi bias-bias kultur di dalamnya; (2) kesadaran dan pemahaman tata pandang siswa yang berbeda kultur; dan (3) pengembangan dan penerapan strategi di dalam mengambil sikap dan perilaku dalam konteks hubungan sosial yang efektif.

Siswa yang memiliki kesadaran keberagaman kelompok dan multikultural adalah: (1) siswa yang bergerak menuju kesadaran kultur, sensitif terhadap warisan kultur sendiri serta menilai dan menghargai perbedaan; (2) sadar akan nilai-nilai dan bias-bias dirinya dan bagaimana hal itu memengaruhi terhadap siswa yang termasuk memiliki kelompok kultur SD secara minoritas; (3) menerima adanya perbedaan antara dirinya dan siswa lain dalam hal ras, gender, identitas, orientasi seksual, sosio demografi dan adanya orientasi yang tidak menilai penyimpangan terhadap perbedaan; (4) sensitif terhadap keberadaan sekitar (bias individu, ras, gender, identitas, orientasi seksual, pengaruh sosial politik) yang dibawa oleh siswa lain dalam konteks hubungan sosial bersama.

Menurut Sue dan Sue (2003), indikator kesadaran multikultural meliputi: (1) meyakini pentingnya kepekaan dan kesadaran pada warisan budaya setiap individu siswa; (2) menyadari latar belakang dan pengalaman-pengalaman budaya yang dapat memengaruhi sikap dan nilai-nilai serta bias-bias terhadap proses psikologis; (3) mengenali batas kemampuan dan dan keahlian diri sendiri pada keragaman budaya; (4) mengenali sumber rasa ketidaknyamanan ketika berhubungan dengan sesama siswa yang memiliki kultur yang berbeda, (5) menyadari reaksi emosi negatif dan positif pada siswa lain yang berbeda kultur yang terkadang mengacaukan keharmonisan hubungan antara sesama siswa, (6) berani mempertentangkan keyakinan dan perilakunya dengan teman sesama siswa yang memiliki perbedaan kultur tanpa menghakimi, (7) menyadari stereotip terhadap kelompok ras, etnis dan siswa minoritas, (8) menghargai nilai-nilai agama tertentu, karena hal ini memengaruhi tata pandang dan fungsi psikososial, (9) menghargai ragam bahasa daerah dan menilai perbedaan bahasa bukanlah penghambat terciptanya hubungan sosial yang baik. 


\section{METODE}

Penelitian ini dilaksanakan dengan menggunakan desain penelitian deskriptif. Sampel diambil secara acak di Sekolah Dasar Laboratorium Universitas Negeri Malang. Sampel diambil di kelas 3 dan 4 Sekolah Dasar. Waktu penelitian berlangsung selama 3 bulan, mulai bulan September s/d November 2016. Instrumen pengukuran yang digunakan ialah skala kesadaran kebhinekatunggalikaan yang dikembangkan sendiri oleh peneliti. Kesadaran bhineka tunggal ika untuk siswa sekolah dasar disusun dalam bentuk gambar berwarna, dan siswa dipersilahkan memilih gambar yang sesuai dengan keinginan mereka. Analisis data dilakukan dengan menggunakan teknik analisis data statistik deskriptif.

\section{HASIL}

Model Cognitive Stage Experiential (CSE) adalah seperangkat langkah dan teknik yang dirancang dan dikembangkan secara khusus untuk meningkatkan kesadaran bhineka tunggal ika siswa SD. Model Cognitive Stage Experiential (CSE) belum pernah dilaksanakan sebelumnya, oleh karena itu, sebelum dilaksanakan eksperimen, para calon pengguna, dalam hal ini guru sekolah yang ditugasi melaksanakan tindakan eksperimen diberi pelatihan. Pelatihan dilakukan dengan tujuan agar guru dapat menjalankan perangkat Model Cognitive Stage Experiential (CSE) secara benar, sesuai dengan urutan dan prinsip yang ditetapkan. Pengetahuan yang cukup dan pengalaman yang memadai akan menyebabkan guru dapat bekerja dengan baik.

Dalam melaksanakan tindakan eksperimen, dari lembar observasi yang telah disediakan, guru telah mampu melaksanakan eksperimen sesuai dengan ketentuan yang ditetapkan. Urutan penyajian, tahapan yang ditetapkan serta penyajian beberapa materi yang telah dirumuskan sebelumnya berjalan sesuai dengan ketentuan yang telah disiapkan.

Sebelum dilaksanakan eksperimen, kepada seluruh partisipan diberikan tes awal dengan menggunakan Skala Kesadaran bhineka tunggal ika yang hasilnya dapat disajikan pada tabel 1.

Dari tabel 1 diketahui bahwa rerata skor konversi kelompok eksperimen 82,59 dan rerata skor konversi kelompok kontrol 83,20. Skor maksimal masing-masing sebesar 95 dan 94 dan skor minimal masing-masing 63 dan 67. Dilihat dari data bahwa sebelum dilaksankan, partisipan yang mencapai skor konversi dibawa kriteria minimal (KM) adalah sangat besar. Kelompok 1 (64 \%), kelompok 2 (53,3\%), kelompok $3(48,4 \%)$ dan kelompok 4 (51,7\%). Dari sisi pencapaian kriteria minimal, maka dapat dikatakan bahwa partisipan SD sebagian besar memiliki kesadaran bhineka tunggal ika rendah. Oleh sebab itu, selanjutnya sangat perlu diberikan pendekatan yang efektif untuk meningkatkan kesadaran bhineka tunggal ika partisipan, dalam hal ini peneliti mengembangkan dan menerapkan pendekatan Psikoedukasi Model Cognitive Stage Experiential (CSE).

Berdasarkan hasil pengukuran awal bahwa partisipan yang memiliki skor konversi di bawah kriteria minimal (KM) sangatlah tinggi. Setelah diketahui bahwa antara kelompok eksperimen dan kelompok kontrol memiliki perbedaan yang signifikan, selanjutnya dengan menerapkan model Cognitive Stage Experiential (CSE) dilaksanakan melalui pendekatan Psikoedukasi konvensional diberikan kepada kontrol dan melalui pendekatan Psikoedukasi menggunakan model Cognitive Stage Experiential (CSE) diberikan kepada kelompok eksperimen. dilaksanakan 4 tahap, disajikan 8 kali pertemuan dengan memberikan tes awal sebelum dimulainya tahap I dan setiap tahap disajikan sebanyak 2 kali pertemuan. Deskripsi singkat pelaksanaan Psikoedukasi dengan model Cognitive Stage Experiential (CSE) disajikan dibawah ini.

\section{Tahap I Adalah Memperhatikan Kesadaran Dualism.}

Tahap I ini merupakan tahap yang memiliki tujuan paling umum, dimana guru pelaksana mencoba berupaya melakukan indentifikasi dan klarifikasi pikiran-pikiran dan emosi partisipan. Tahap ini dilaksanakan 2 kali pertemuan. Partisipan diberikan penjelasan singkat mengenai peran dan pentingnya hubungan baik sesama orang. Setelah itu, paritisipan diajak untuk mengamati dan 
Tabel 1 Hasil Tes Awal Kesadaran Bhineka Tunggal Ika Partisipan

\begin{tabular}{lcccc}
\hline \multirow{2}{*}{ Kelompok } & \multicolumn{4}{c}{ Hasil Tes Awal } \\
\cline { 2 - 5 } & Min & Maks & Rerata & $\begin{array}{l}\text { KM } \\
(\%)\end{array}$ \\
\hline Kelas-A & 20 & 92 & 45.44 & 59 \\
Kelas-B & 17 & 90 & 45.04 & 59 \\
Kelas-C & 19 & 91 & 45.01 & 59 \\
\hline
\end{tabular}

mencermati tayangan pesan virtual selama 12 menit. Pokok-pokok pikiran yang sengaja dilontarkan adalah sekitar masalah terjadinya saling membantu anak yang berasal dari daerah dan suku yang berbeda yang berdampak baik bagi keharmonisan orang lain. Di samping itu, partisipan juga diajak untuk menghayati dan merasakan secara emosi kedalam situasi dan peristiwa yang terjadi. Dalam pertemuan pertama, partisipan sangat antusias dan perhatian penuh. Refleksi dan reaksi spontan mereka terhadap tayangan peristiwa dan buku kerja. Kemudian diikuti oleh respon-respon mereka secara verbal, yang menggambarkan kesenangan partisipan terhadap "figur" yang secara nyata berbeda secara fisik dan budaya, dimana "figur" digambarkan sedang menjalani kehidupan sesuai dengan kebiasaan dan adat. Bahkan, dampak positif yang ditimbulkan dapat saling memahami dan merasa memiliki. Berikutnya adalah pertemuan kedua tahap ini.

Dalam pertemuan kedua, partisipan dihadapkan pada suatu gambar yang mencerminkan budaya daerah tertentu. Menyenangkan bagi sekelompok anggota masyarakat yang hidup dan tinggal di suatu daerah yang sangat jauh. Respon kognitif dan emosi yang diharapkan timbul dari partisipan adalah betapa dirinya berbahagia. Kehidupan yang serba mudah menjadi landasan cara berpikir yang sengaja ditanamkan. Empati, semangat, bersedia menolong dan berbagi serta berparisipasi adalah elemen karakter dan kerangka pikir yang sengaja ditanamkan. Keberadaan figur contoh yang ditampilkan melalui video berdurasi 5 menit ini menjadi fokus adalah keberagaman budaya yang sangat mencerminkan kekayaan budaya bangsa. Kesederhanaan dan kesetaran adalah jawaban untuk menghargai peristiwa tersebut.

Dalam prosesnya tahap ini cukup dinamis, ditandai oleh pengisian lembar kerja yang berupa lembar intruksi diri yang terbukti dapat menumbuh kembangkan sikap positif bagi partisipan. Dalam pengisian lembar intruksi diri, partisipan memiliki respon yang bervariasi.

Terhadap penampilan oleh "figur" dalam tayangan maupun buku ajar banyak partisipan yang bicara "miris", "kita bantu", dan yang memberikan makna penting ialah hampir sebagian besar partisipan ingin berkenalan. Hasil yang dapat diamati selama proses disamping yang tertuang dalam instruksi diri adalah respon verbal dan non verbal yang ditunjukkan selama proses. Perenungan dan respon-respon positif seperti menunduk kepala setelah melihat tayangan, memerhatikan serempak seperti hening adalah penampakan dalam proses.

\section{Tahap II Adalah Membangkitkan Kesadaran Multiplicity}

Sentuhan utama dalam tahap ini adalah terjadinya proses internalisasi pada diri partisipan dengan melalui sejumlah teknik yang diterapkan. Sumber pesan virtual yang ditampilkan dan gambar yang dituangkan dalam buku ajar adalah surat yang dibcakan oleh sebagian partisipan sebagai proses pengalaman. Inspirasi munculnya semangat kerja dan belajar keras guna meraih cita-cita dan tidak putus asa dalam belajar adalah fokus persoalan yang ditonjolkan. Berbeda dengan tahap 1 , tahap dua ini memiliki peningkatan isu yang ditampilkan. Terdapat sejumlah tokoh yang sempat menjadi perhatian dunia. Kekayaan budaya menjadi inspirasi timbulnya emosi senang terhadap budaya sendiri, yang pada gilirannya menjadi meluas kepada sikap senang terhadap sumber budaya dan pemilik budaya asal.

Dalam pertemuan ke 3 dan 4 ini, partisipan diberikan penguatan terhadap pentingnya menetapkan pandangan hidup secara rasional, sesuai dengan kenyataan serta memungkinkan untuk dapat dicapai. Istilah mimpi adalah masa depan yang belum tercapai adalah salah satu isu yang 
menjadikan partisipan tetap dalam kondisi fit untuk menghadapi segala tantangan. Kepercayaan adalah modal yang tak ternilai harganya, optimis dan pandangan luas menjadi motor penggerak yang mempertahankan energi psikis untuk berkembang dan mencapai tujuan, sedang semangat dan fleksibel merupakan modal yang harus ada dalam diri setiap orang yang mau maju. Problemproblem yang mungkin dapat terjadi pada diri partisipan sehubungan dalam pencapaian tujuan kebersamaan dengan orang lain merupakan fokus pembahasan dalam proses penerapan teknik. Hasil yang dapat diamati selama proses adalah munculnya sikap optimis dan cinta sesama yang ditampakkan melalui sesi tanya jawab yang dipandu oleh guru pelaksana dengan teknik pemecahan masalah. Masalah-masalah yang dimunculkan adalah masalah yang didasarkan pada estimasi dari tayangan pesan virtual dan buku ajar yang bersumber dari semangatnya kebersamaan sesama bangsa. Dalam tayangan pesan virtual dan gambar dalam buku ajar juga ditunjukkan adanya anak yang memiliki kepiawaian mencintai budaya. Rasa terharu dari para apartisipan sempat terlontar dalam respon verbal dan tertulis.

\section{Tahap III Adalah Kesadaran Relativism}

Hasil yang dapat diamati selama proses ialah ungkapan tertulis yang diberikan oleh partisipan, seperti misal mereka menginginkan kenali dirinya lebih dekat untuk merencang tujuan masa depan yang lebih baik. Memahami sisi-sisi lain kehidupan yang memungkinkan orang berbuat baik untuk tujuan bersama, dan berupaya mengejar prestasi dan mengelola waktu dengan baik. Ungkapan tersebut disodorkan secara tertulis oleh para partisipan dalam sebuah lembaran yang disebut rencana perubahan perilaku.

\section{Tahap IV Adalah Kesadaran Commitment}

Tahap ini merupakan tahap finalisasi Psikoedukasi. Partisipan diajak untuk mengalami secara pikiran dan emosi dengan adanya peristiwa membaca pantun anak-anak. Pantun yang dibacakan oleh sebagian anak sangat menggugah pikiran dan emosi setiap pemirsanya. Partisipan diajak untuk membuat rencana baru mulai dari cinta diri sendiri dan orang lain, dan cinta tanah air serta merasa sama dan senasib dengan sesama teman, keinginan untuk mewujudkan cita-cita yang didukung oleh orang banyak dan kebanggaan terhadap keharmonisan yang terbentuk dalam setiap kelompok remaja di masyarakat. Tujuan hidup yang berupa kenyamanan di masyarakat, kesamaan hak dan kewajiban, saling adanya kepercayaan dan dipercaya, tindakan pro kemanusiaan dan bersedia menolong orang adalah merupakan bagian hidup yang utama. Hal tersebut menjadi pendorong bagi terciptanya keharmonisan hidup bermasyarakat. Bersedia menolong, berbagi, berpartisipasi serta menghargai sesama adalah bukti nyata dari konsep-konsep tersebut. Semua itu akan mengarah kepada sebuah energi psikis yang menggambarkan partisipan yang hidup dengan semangat juang dan reformis.

Dalam prosesnya, Cognitive Stage Experiential (CSE) memiliki karakter proses yang unik. Hal tersebut, di samping memang model Cognitive Stage Experiential (CSE) yang diterapkan merupakan model baru yang diketahui oleh guru, juga model Cognitive Stage Experiential (CSE) merupakan model yang tidak dikembangkan sendiri oleh guru. Oleh karena itu, dalam proses guru diamati dengan menggunakan instrumen pengamatan. Kriteria penilaian terdiri dari 6 komponen dengan jumlah total 22 butir yang dinilai dalam rentangan 1-5. Dalam kesimpulan akhir, skor akan ikut dipertimbangkan apakah guru dalam melaksanakan Cognitive Stage Experiential (CSE) telah melaksanakan sesuai kriteria yang didasarkan pada pencapaian skor minimal yaitu 80 persen dari maksimal nilai. 6 komponen tersebut meliputi: (1) mengelola ruang dan fasilitas Cognitive Stage Experiential (CSE) yang meliputi penyiapan ruang, alat bantu dan sumber serta pelaksanaan tugas harian kelas; (2) melaksanakan kegiatan Psikoedukasi model Cognitive Stage Experiential (CSE) dengan benar yang mencakup kegiatan memulai kegiatan Cognitive Stage Experiential (CSE), melaksanakan jenis kegiatan yang sesuai dengan tujuan, partisipan, situasi dan lingkungan, menggunakan alat bantu (media) Cognitive Stage Experiential (CSE) yang sesuai dengan tujuan, partisipan dan lingkungan, serta melaksanakan kegiatan Cognitive Stage Experiential (CSE) 
dalam urutan yang logis; (3) mengelola interaksi kelas yang mencakup kegiatan memberi petunjuk dan penjelasan yang berkaitan dengan isi Cognitive Stage Experiential (CSE), menangani pertanyaan dan respon partisipan, menggunakan ekspresi lisan, tulisan, isyarat dan gerakan badan, memicu dan memelihara keterlibatan partisipan, serta memantapkan penguasaan materi Cognitive Stage Experiential (CSE); (4) bersikap terbuka dan luwes serta membantu mengembangkan sikap positif partisipan termasuk kegiatan yang menunjukkan sikap ramah, hangat, luwes, terbuka, penuh pengertian, sabar kepada partisipan, menunjukkan sikap ramah, hangat, luwes, terbuka, penuh pengertian, sabar kepada partisipan, menunjukkan kegairahan memberi layanan, mengembangkan hubungan antar pribadi yang sehat dan serasi, membantu partisipan menyadari kelebihan dan kekurangannya; (5) melaksanakan evaluasi proses dan penilaian yang meliputi kegiatan melaksanakan penilaian selama proses Cognitive Stage Experiential (CSE), melaksanakan penilaian pada akhir Cognitive Stage Experiential (CSE), serta; (6) kesan umum kinerja guru yang mencerminkan keefektifan proses Cognitive Stage Experiential (CSE), penggunaan bahasa Indonesia lisan, peka terhadap kesalahan berbahasa lisan dan penampilan guru dalam Cognitive Stage Experiential (CSE). Dari 4 guru pelaksana, mendapat skor masing-masing guru 1=97, guru 2=94, guru 3 dan 4 masing-masing 92. Kesimpulannya untuk guru yang mendapatkan skor 92 maka setelah konversi skala 100 menjadi $92: 110$ x $100 \%=83$. Untuk guru yang mendapatkan skor diatas 92 berarti mereka mendapat hasil skor yang lebih baik. Kesimpulannya bahwa Cognitive Stage Experiential (CSE) telah dilaksanakan oleh guru dengan baik.

\section{Deskripsi Data}

\section{Deskripsi Data Hasil Tes Awal}

Sebelum dilaksanakan eksperimen, terhadap seluruh kelompok diberikan tes awal. Tes awal dilakukan dengan tujuan agar diketahui data-data awal mengenai variabel kesadaran bhineka tunggal ika partisipan. Data awal diperlukan untuk menetapkan desain yang tepat untuk eksperimen. Salah satu data yang penting diketahui ialah apakah partisipan yang masuk dalam kelompok (baik eksperimen maupun kontrol) bersifat homogen antar kelompok. Jika homogen maka selanjutnya secara acak akan dilakukan pengelompokan. Untuk mencapai tujuan tersebut, dilakukan analisis komparatif desain ANOVA satu jalur. ANOVA satu jalur dipilih karena sampel (partisipan) berjumlah 4 sel.

\section{Deskripsi Data Hasil Tes Kesadaran Bhineka Tunggal Ika Partisipan}

Analisis data deskriptif bertujuan untuk mengetahui hasil pengukuran dasar terhadap kesadaran Bhineka Tunggal Ika partisipan (baik sebelum maupun sesudah eksperimen). Secara ringkas, data ditampilkan dalam tabel 2.

Tabel 2 menunjukkan bahwa skor rerata tes awal kesadaran bhineka tunggal ika kelompok eksperimen adalah 45.44. Pencapaian skor minimal yang diperoleh oleh masing-masing partisipan adalah 20. Skor rerata tes akhir kesadaran bhineka tunggal ika (setelah perlakuan) adalah 52.96. Pencapaian skor minimal yang diperoleh oleh masing-masing partisipan adalah 25 dan skor maksimal adalah 92. Skor rerata tes awal kesadaran bhineka tunggal ika kelompok kontrol adalah 45.04. Pencapaian skor minimal yang diperoleh oleh masing-masing partisipan adalah 17.

Pada pengukuran awal partisipan yang mencapai skor konversi di bawah kriteria minimal masing-masing kelompok sebanyak 30 dari 120 partisipan (25\%). Data ini menunjukkan bahwa sangat tinggi partisipan yang mencapai hasil tes di bawah kriteria minimal (KM) mencapai $75 \%$. Seluruh data deskriptif di atas menunjukkan bahwa berdasarkan nilai rerata yang dicapai masingmasing kelompok maupun pencapaian skor di bawah kriteria minimal menunjukkan bahwa ada kecenderungan hasil kesadaran bhineka tunggal ika partisipan pada pengukuran kedua untuk kelompok eksperimen adalah lebih tinggi dari pengukuran awal. 
Tabel 2 Deskripsi Hasil Tes Kesadaran Bhineka Tunggal Ika Partisipan

\begin{tabular}{lcccc}
\hline \multirow{2}{*}{ Kelompok } & \multicolumn{4}{c}{ Hasil Pengukuran } \\
\cline { 2 - 5 } & Min & Maks & Rerata & $\begin{array}{l}\text { KM } \\
(\%)\end{array}$ \\
\hline Kelas-A & 20 & 92 & 45.44 & 59 \\
Kelas-B & 17 & 90 & 45.04 & 59 \\
Kelas-C & 19 & 91 & 16.01 & 59 \\
\hline
\end{tabular}

Gambar 1 menunjukkan bahwa siswa SD kelompok-A 120 siswa mendapatkan nilai kesadaran bhineka tunggal ika 51 (42.5\%) masuk kategori sangat rendah, disusul kategori rendah 24 (20\%), sedang $32(27 \%)$, tinggi $6(5 \%)$ dan sangat tinggi $7(6 \%)$. Data ini menunjukkan bahwa kesadaran bhineka tunggal ika siswa sekolah dasar sangat rendah. Jika nilai siswa yang termasuk kategori sangat rendah digabung dengan kelompok siswa yang memiliki kategori rendah mencapai $62 \%$. Hal ini menunjukkan bahwa siswa sekolah dasar perlu mendapat asupan layanan bimbingan yang dapat meningkat kesadaran bhineka tunggal ika.

Gambar 2 menunjukkan bahwa siswa SD kelompok-B yang terdiri dari 116 siswa nilai kesadaran bhineka tunggal ika 50 (43\%) masuk kategori sangat rendah, disusul kategori rendah $23(20 \%)$, sedang 29 (25\%), tinggi 10 (9\%) dan sangat tinggi 4 (3\%). Data ini menunjukkan bahwa kesadaran bhineka tunggal ika siswa sekolah dasar sangat rendah. Jika nilai siswa yang termasuk kategori sangat rendah digabung dengan kelompok siswa yang memiliki kategori rendah mencapai $66 \%$. Hal ini menunjukkan bahwa siswa sekolah dasar perlu mendapat asupan layanan bimbingan yang dapat meningkat kesadaran bhineka tunggal ika.

Gambar 3 menunjukkan bahwa siswa SD kelompok-C nilai kesadaran bhineka tunggal ika 47 (41\%) masuk kategori sangat rendah, disusul kategori rendah $26(22 \%)$, sedang 30 (26\%), tinggi 8 (7\%) dan sangat tinggi 5 (4\%). Data ini menunjukkan bahwa kesadaran bhineka tunggal ika siswa sekolah dasar sangat rendah. Jika nilai siswa yang termasuk kategori sangat rendah digabung dengan kelompok siswa yang memiliki kategori rendah mencapai $67 \%$. Hal ini menunjukkan bahwa siswa sekolah dasar perlu mendapat asupan layanan bimbingan yang dapat meningkat kesadaran bhineka tunggal ika.

\section{PEMBAHASAN}

Ciri khas model Psikoedukasi Cognitive Stage Experiential adalah perhatian penuh secara seimbang antara tahap perkembangan kognitif dan siklus pembelajaran Experiential. Baik pikiran maupun emosi merupakan bagian kepribadian yang memiliki pengaruh kuat bagi terpenuhinya kriteria tingkah laku sehat. Emosi memiliki pola tindakan fisiologis khas yang berbeda dan ditentukan oleh pengalaman hidup. Oleh karena itu hanya makhluk manusia yang memiliki variasi reaksi emosi dan aturan (norma) yang digunakan dalam mengendalikan reaksinya. Pengalaman emosi masa lalu setiap individu akan berpengaruh terhadap pola reaksi emosi dan tindakan fisiologisnya. Apakah suatu reaksi emosi didasarkan pada aturan budaya yang telah baku dan diakui bersama sebagai nilai dan norma budaya, ataukah menentang aturan budaya tersebut. Keduanya, baik yang mengikuti dasar nilai dan norma budaya maupun yang menentang memiliki dampak reaksi dan konsekuensi yang tentu berbeda, selanjutnya menjadi sebuah pengalaman emosional yang berbeda. Oleh karena itu proses-proses refleksi masa lalu dan refleksi peristiwa-peristiwa emosional orang lain menjadi bahan bagi proses rekonstruksi pembentukan pengalaman baru, dan ini yang disebut sebagai proses pengalaman yang dirancang lebih baik. Tugas guru adalah mendampingi siswa untuk dapat menjalankan fungsinya dalam rekonstruksi pengalaman masa lalu yang kurang menguntungkan menjadi sebuah pengalaman baru yang sangat menguntungkan bagi semua pihak. Kesadaran dini kebhinekatunggalikaan merupakan kondisi emosi dan pikiran yang secara konsisten dan menjadi ciri serta penggerak perilaku dan sikap. Jika seorang anak secara dini telah memiliki 
186 | Jurnal Kajian Bimbingan dan Konseling, 1 (4), 2016, 179-188

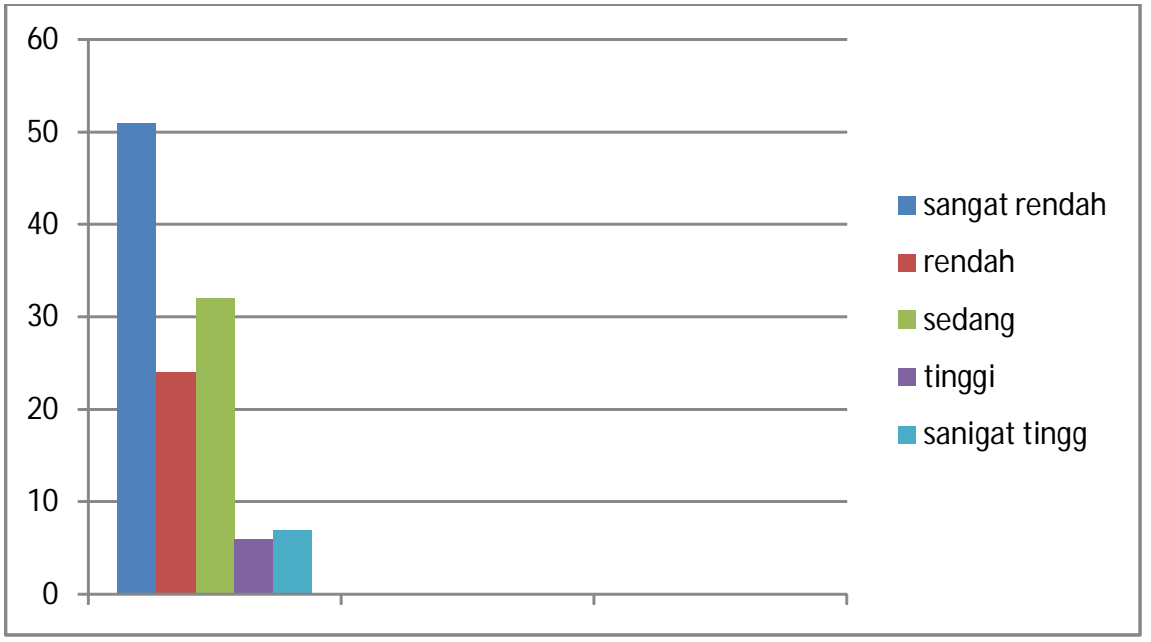

Gambar 1 Hasil Tes Awal Kelompok-A

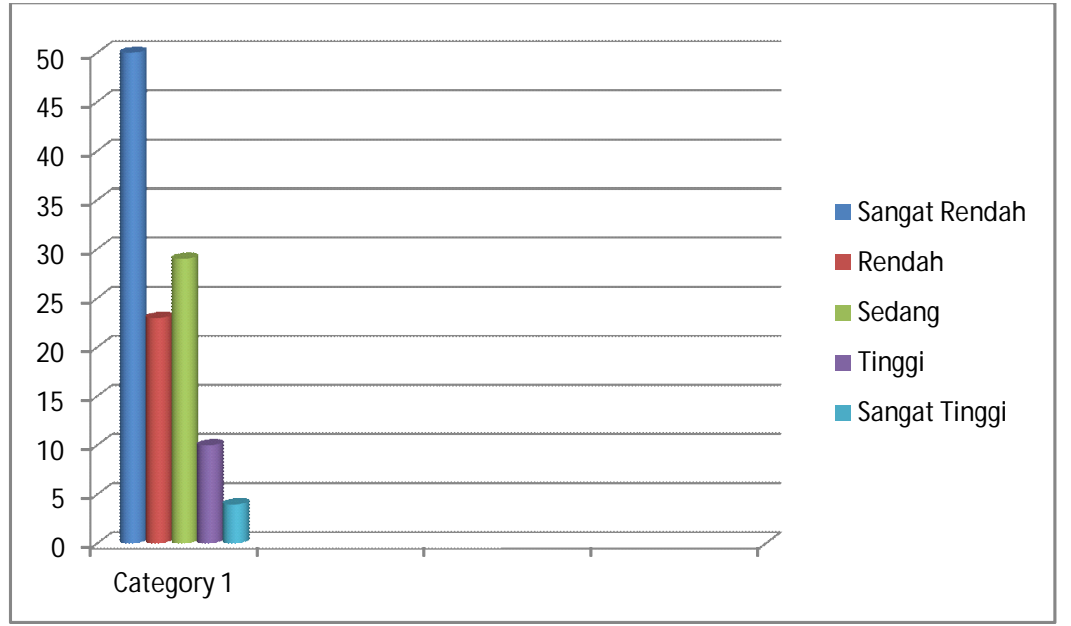

Gambar 2 Hasil Tes Awal Kelompok-B

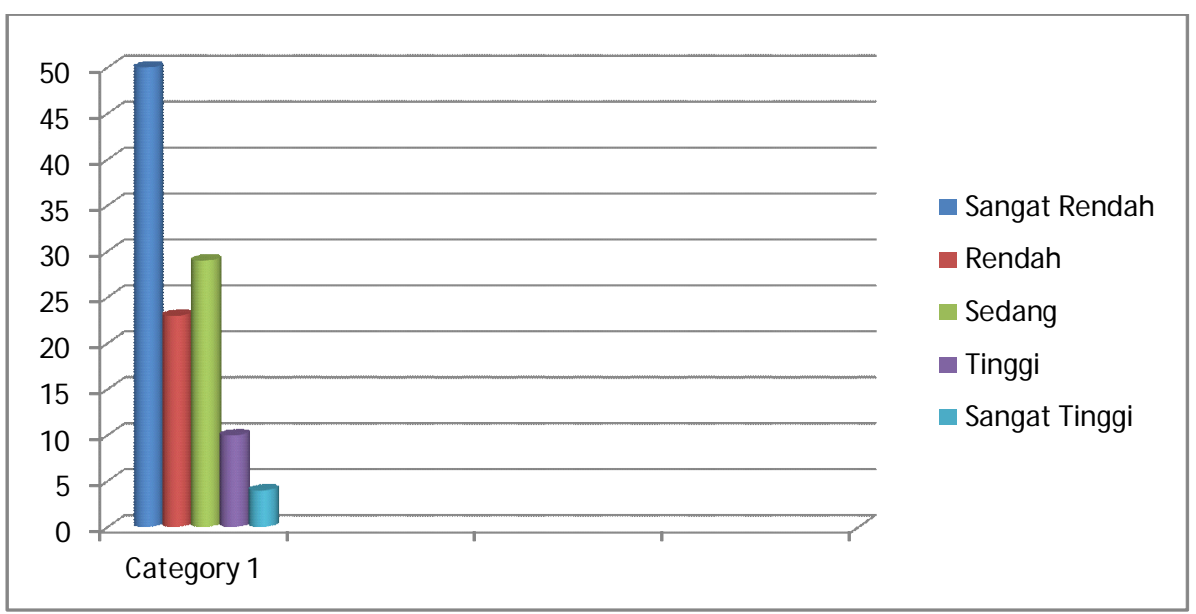

Gambar 3 Hasil Tes Awal Kelompok-C 
kesadaran yang baik, maka kesadaran itu akan diaktulisasikan dalam setiap langkah dan tahap perkembangan hidupnya. Oleh karena itu, treatment secara dini akan membentuk kepribadian yang konstruktif.

\section{SIMPULAN}

Hasil penelitian menunjukkan bahwa: (1) proporsi tingkat kesadaran bhineka tunggal ika yang masuk kategori sangat rendah adalah $42.5 \%, 43 \%$ dan $41 \%$; (2) proporsi tingkat kesadaran bhineka tunggal ika yang masuk kategori rendah adalah 20\%, 20\%, dan 22\%; (3) proporsi tingkat kesadaran bhineka tunggal ika yang masuk kategori sedang adalah 27\%, 25\%, dan 26\%; (4) proporsi tingkat kesadaran bhineka tunggal ika yang masuk kategori tinggi adalah 5\%, 9\%, 7\%; (5) proporsi tingkat kesadaran bhineka tunggal ika yang masuk kategori sangat tinggi adalah 6\%, 3\%, 4\%.

Dari hasil penelitian ini disarankan: (1) hendaknya ada penelitian lanjut untuk mengetahui bagaimanakah kondisi keluarga bagi anak yang memiliki kesadaran bhineka tunggal ika sangat tinggi; (2) ada penelitian lanjut untuk mengetahui bagaimanakah kondisi keluarga bagi anak yang memiliki kesadaran bhineka tunggal ika sangat rendah; (3) guru Sekolah Dasar hendaknya telah mengenalkan dengan metode yang tepat mengenai bhineka tunggal ika.

\section{DAFTAR RUJUKAN}

Archer, S. L. 1994. Intervention for Adolescent Development, Newbury Park: Sage Publication.

Carkhuff, R. R. \& Anthony,W. A. 1984. The Skills of Helping. Amhetst, Massachusetts: Human Resources Development Press. Inc.

Cook, L. S. \& Olson, J. R. 2006. The Sky's The Limit: An Activity for Teaching Project Management: Journal og Management Education, 30(3),404-420).

Cox, T. \& Ruby, L. B. 1997. Developing Competency to Manage Diversity: Reading, Cases, and Activities. San Fransisco: Berret-Koehlier Publisher.

Dick, W. \& Carey, L. 1987. The Systematic Design of Instruction. Dalam Munandir (penerj.) Rancangan Sistem Pengajaran. Jakarta: Proyek Pengembangan Lembaga Pendidikan Tenaga Kependidikan, Ditjen Dikti. (tidak diterbitkan).

Gambino,T. W. \& Super, D. E. 1982.Career and Vocational Education: Integrating The Concepts. Dalam C.R Doty Ed). Career Education and The Affective Domain:Choice, Succes, Concepts,Survival Skills,Testing. (pp.56-82).Trenton,New Jersey:New Jersey State Department of Education.

Gustafson, K.L. 1981. Survey of Instructional Development Model. Athens, Georgia: Clearinghouse on Information Resource.

Joni, T. R. 1993. Penilaian Hasil Belajar Melalui Pengalaman dalam Program S1 Kedua Pendidikan Bidang Studi SD. Jakarta: Konsorsium Ilmu Pendidikan,Ditjen Dikti.

Joyce, B. R. \& Weil, M. 1978. Information Processing Models of Teaching. Englewood Clifts,N.J: Prentice Hall,Inc.

Kolb, D. 1984. Experiential Learning: Experience as The Source of Learning and Development. Englewood Clifts,N.J: Prentice Hall,Inc.

Locke, D.1992. Increasing Multiculral Understading: a Comprehensive Model. Newbury Park California: Sage Publication.

Perry, W. G. 1999. Forms of Ethical and Intellectual Development in The College Years: A Scheme. San Fransisco:Jossey-Bass Publisher.

Sue, D. W. \& Su, D. 2003. Counseling Culturally Diverse: Theory and Practice.Fouth Edition. USA:John Wiley \& Sons.Inc

Sue, D. W. 2001. Multidimentional Facets of Cultural Competence.The Counseling Psychologist. (29), 6, 790-821. 
188 | Jurnal Kajian Bimbingan dan Konseling, 1 (4), 2016, 179-188

Sue, M. G. 2005. Strategies for Building Multicultural Competence in Mental Health and Educational Setting. New Jersey: John Wiley \& Son.

Turesky, E. F. \& Mundenk, L. G. 2008. Going Beyond Traditional Career Development Theories: Individualizing Counseling Using Cognitive Stage and Experiential Learing Theories. Canadian Journal Of Career Development/Revue Canadienne de developpement de Carrier.7,(2) 3-7.

Waak, J. L. D \& Donogian, J. 2004. The Practice of Multicultural Group Work: Vision and Perspectives from the field. Canada:Thomson. Books/Cole. 